\title{
The Regulatory Role of Syndecan-1 on Human MiR-222-3p Expression in Breast Cancer Cell Lines
}

\author{
Original Sahar Mohamed Ibrahim, Amel I. Othman', Hebatallah Hassan ${ }^{1}$, \\ Article Sherif Abdelaziz Ibrahim ${ }^{1}$ and Martin Götte ${ }^{2}$ \\ ${ }^{1}$ Department of Zoology, Faculty of Science, Cairo University. \\ ${ }^{2}$ Department of Gynecology and Obstetrics, University Hospital Münster, Münster, Germany.
}

\begin{abstract}
Introduction: MicroRNAs (miRNAs), small non-coding endogenous RNA molecules whose length ranging from 18-25 nucleotides, are implicated in regulating many physiological and pathological processes, including cell proliferation and apoptosis, adhesion, migration, invasiveness, epithelial-to-mesenchymal transition and the cancer stem cell properties. These molecules regulate gene expression at the posttranscriptional level by inducing mRNA degradation or translational repression. It was reported in previous work that miR-222-3p expression and Syndecan-1 (SDC-1) silencing regulate the aggressiveness of primary breast cancer and its metastasis. SDC-1, a cell surface heparan sulphate proteoglycan acting as a co-receptor for many growth factor receptors, is known to regulate the expression of many miRNAs. However, its impact on miR-222-3p expression in breast cancer is still unclear.

Aim of the Work: To investigate the effect of SDC-1 silencing on the expression of hsa-miR-222-3p in the human breast cancer cell lines.

Materials and Methods: We used the human breast cancer cell lines MCF-7 (low invasive) and MDA-MB-231 (highly invasive), which were transfected with $20 \mathrm{nM}$ control and SDC-1 siRNA.hsa-mir-222-3p expression was analyzed by quantitative PCR (qPCR) in control and SDC-1-silenced cells $48 \mathrm{~h}$ post transfection. Moreover, the expression of $\beta$-catenin protein72h post SDC1 knockdown was assessed by Western blotting.

Results: No significant change was observed for the expression levels of hsa-miR-222-3p and $\beta$-catenin protein after SDC-1 knockdown neither in MCF-7 nor MDA-MB-231 cell lines.

Conclusion: SDC-1 is not a regulator for miR-222-3p expression and the altered cell behavior mediated by SDC-1 knockdown in MCF-7 and MDA-MB-231 breast cancer cells is miR-222-3p-independent.
\end{abstract}

Received: 15 February 2019, Accepted: 18 February 2019

Key Words: $\beta$-catenin, breast cancer, hsa-miR-222-3p, SDC-1.

Corresponding Author: Sherif Abdelaziz Ibrahim, PhD, Department of Zoology, Faculty of Science, Cairo University, Giza, Egypt, Tel.: +20 1004858517, Email: isherif@sci.cu.edu.eg

ISSN: $1110-0559$, Vol. 42, No. 3

\section{INTRODUCTION}

GLOBCAN 2018 reported that breast cancer is the second cause of mortality related to cancer worldwide after lung cancer by $11.5 \%^{[1]}$. It is considered the most commonly diagnosed cancer and the first leading cause of cancer death among females. In 2018 about 2,088,849 cases were diagnosed with breast cancer $(11.6 \%$ of all cases diagnosed with cancer) and about 626,679 cases were recorded to die because of breast cancer $\left(6.6 \%\right.$ of death cases by cancer ${ }^{[1]}$. Although the survival rate is improved dramatically due to the advanced screening and early treatment, but it is still a major threaten for females in developing countries. It was estimated that breast cancer ranks the second cancer incidence by $32.0 \%$ among Egyptian females and that proportion will be elevated by 3 -fold by 2050 relative to its incidence in $2013^{[2]}$.
Syndecan-1/CD138 (SDC-1) is a cell surface heparan sulphate proteoglycan that is intensively expressed by plasma and epithelial cells ${ }^{[3]}$. SDC-1 can bind to many of angiogenic and growth factors through its heparan sulphate chains and acts as a cell surface co-receptor for growth factor receptors promoting cell proliferation ${ }^{[4]}$.In addition, SDC-1 acts as a cell adhesion molecule through its interaction with various ligands in the extracellular matrix (ECM) and on the cell surface ${ }^{[5]}$. SDC-1 affects the expression of many microRNAs (miRNAs) in a wide range of cancer entities. This could be originated from its ability to regulate many transcription factors such as nuclear factor kappa $\mathrm{B}^{[6]}$ and $\mathrm{p} 53^{[7]}$.

MiRNAs are small non-coding endogenous RNA molecules whose length from 18 to 25 nucleotides and act as post transcriptional regulators ${ }^{[8]}$. A single miRNA 
can target several mRNAs that are involved in the tumorgenesis ${ }^{[9]}$. Fuji et al. showed that the silencing of SDC-1 resulted in a decrease in the expression of hsa-mir149-5p and hsa-mir-126 in prostate cancer ${ }^{[10]}$. Moreover, SDC-1 knockdown was shown to decrease the expression of mature hsa-mir-331-3p via controlling Dicer expression which in turn mediated the epithelial- mesenchymal transition (EMT) in prostate cancer ${ }^{[11]}$. MiR-221/222 is a miR cluster that influences metastasis by regulating tumor growth, invasion and EMT in many cancers, such as breast cancer ${ }^{[11-15]}$, lung ${ }^{[16]}$, liver cancer ${ }^{[16]}$, pancreatic ${ }^{[17]}$ and colorectal cancer ${ }^{[18]}$. Over expression of mir-222-3p induces the polarization of tumor associated macrophage via targeting SOCS3 in epithelial ovarian cancer ${ }^{[19]}$. Moreover, upregulation of mir-222-3p enhances the proliferation and invasion of endometrial carcinoma cell lines (RL952, AN3CA) via targeting estrogen receptor alpha (ERa) ${ }^{[20]}$. MiR-222 is also involved in the promotion of the aggressive basal-like phenotype in breast cancer promoting EMT in breast cancer via targeting trichohinophalangeal 1 (TRPS1) ${ }^{[21]}$. Over expression of mir-222-3p results in estrogen-independent growth and fulvestrant resistance in estrogen receptor- $\alpha(E R \alpha)$-positive cell lines via $\beta$-catenin activation $^{[13]}$. The aim of this study was to reveal the effect of SDC-1 silencing on the expression of hsa-miR-222$3 p$ in the human low invasive MCF-7 and high invasive MDA-MB-231 breast cancer cell lines.

\section{MATERIAL AND METHODS}

\section{Cell culture}

Human breast cancer cell lines were purchased from ATCC/LGC Promochem (Wesel, Germany).The hormone receptor positive MCF-7 and the triple negative MDAMB-231 cell lines weremaintained in RPMI-1640 and DMEM media (Sigma Aldrich, Deisenhofen, Germany), respectively. Media were supplemented with $1 \%$ Glutamine, 10\% FBS (BiochromGmbH, Berlin, Germany) $1 \%$ penicillin- streptomycin antibiotic (SIGMA) and maintained in a condition of $37{ }^{\circ} \mathrm{C}, 5 \% \mathrm{CO} 2$, and $95 \%$ relative humidity.

\section{SDC-1 Knockdown by cell transfection with SDC-1 $\operatorname{siRNA}$}

For siRNA transfection, the cells were plated into a sixwell plate for 24 hours to reach $60-70 \%$ confluency prior to transfection. transfection was performed using Dharmafect reagent (Dharmacon, Lafayette,CO., USA) in OPTI-MEM medium (Gibco BRL, Karlsruhe, Germany),20 nMSDC-1 siRNA (Ambion, Taxis, USA)and $20 \mathrm{nM}$ negative control siRNA (Negative control \#1, Ambion, Taxis, USA). Transfection was performed according to manufacturer's instructions and after 24 hours of the transfection the media was changed with the fresh corresponding media supplemented with $10 \%$ FBS .

\section{Quantitative Real-Time PCR Analysis}

Total cellular RNA was isolated after 48hours of transfection using InnuPREP RNA mini kit (analytic Jana,
Jana, Germany) according to manufacturer's instructions. RNA concentration and purity were assessed at $260 \mathrm{~nm} / 280$ $\mathrm{nm}$. For cDNA preparation, $1 \mu \mathrm{g}$ oftotal cellular RNA was reverse transcribed into cDNA using High capacity cDNA Reverse Transcription Kit (Applied Biosystems, Darmstadt, Germany) according to manufacturer's instructions and the cDNA was stored at $-20^{\circ} \mathrm{C}$ for further usage. For miRNA quantification, 100ng of total cellular RNA was converted into micro-cDNA using the TaqMan MicroRNA Reverse Transcription Kit with included specific primers for the individual microRNA as described by the manufacturer (ABI). Quantitative PCR (qPCR) was performed using the ABI PRISM 7300 Sequence Detection System (Applied biosystem) using the default thermal cycling conditions as follows; initial activation for 15 minutes at $95^{\circ} \mathrm{C}$ followed by 40 cycles of denaturation for 15 seconds at $94^{\circ} \mathrm{C}$ then annealing/extension steps for 30 seconds at $60^{\circ} \mathrm{C}$. Data analysis were performed using the $2-\Delta \Delta \mathrm{Ct}$ method. This quantification method measures the relative change in the expression level of SDC-1 after normalization to $18 \mathrm{~S}$ rRNA. SDC-1 Taqman probe (Hs00174579_m1) and 18SrRNATaqman probe (Hs99999901_s1) were used.

\section{Sodium dodecyl sulfate- polyacrylamide gel electrophoresis (SDS-PAGE) and immunoblotting (Western blot)}

MCF-7 and MDA-MB-231 negative control siRNA and SDC-1 siRNA transfected cells were washed twice with ice cold PBS and lysed using blue loading buffer (Cell Signaling Technology, Inc., Beverly, MA, United States) according to the manufacturer's instruction. Then, the total cell lysates were sonicated for 10-15 seconds on ice then the lysates were heated for 5 minutes at $95 \mathrm{C}^{\circ}$ and centrifuged for 2-5 minutes A total of $20 \mu \mathrm{g}$ of the cell lysate were loaded onto SDS-PAGE gel and blotted with anti-human- $\beta$-Catenin antibody (Cell Signaling) overnight at $4 \mathrm{C}^{\circ}$. Proteins were visualized with horseradish peroxidase-conjugated secondary antibody followed by chemiluminescence detection. Tubulin was used as a loading control.

\section{Statistical analysis}

Data were presented as mean \pm standard error of the mean (SEM). Statistical analysis was performed using SPSS V0.16 software (Chicago, IL, USA).An unpaired t-test was used to compare between 2 groups and a two sided $p$-value of $<0.05$ was considered statistically significant,. All calculations were performed on the means of triplicate measurements of at least three independent experiments.

\section{RESULTS}

Confirmation of successful SDC-1 Knockdown by $q P C R$

Prior to any experiment, SDC-1 knockdown was verified by qPCR. Our results showed that relative to control SDC-1mRNA expression was significantly 
$(P<0.0001)$ downregulated by $96 \%$ and91\%in SDC1 siRNA-transfected MDA-MB-231 and MCF-7cells, respectively (Figure 1).

\section{Hsa-mir-222-3 pexpression is not regulated by $S D C$ - 1 expression in MCF-7 and MDA-MB-231cells}

The impact of SDC-1 knockdown on expression of hsamiR-222-3p was investigated. Our TaqMan probe-based qPCR results showed nochangeinmiR-222-3p expression (only increased by $10 \%, p>0.05$ ) in both MCF-7 and MDAMB-231 cell lines following SDC-1 depletion (Figure 2).

\section{SDC-1 knockdown has no impact on $\beta$-catenin expression in MCF-7 and MDA-MB-231 cells}

We next tested the effect of SDC-1 silencing on $\beta$-catenin expression by western blot. Our data showed no change of $\beta$-catenin expression in MCF-7 and MDAMB-231 cell lines (Figure 3).

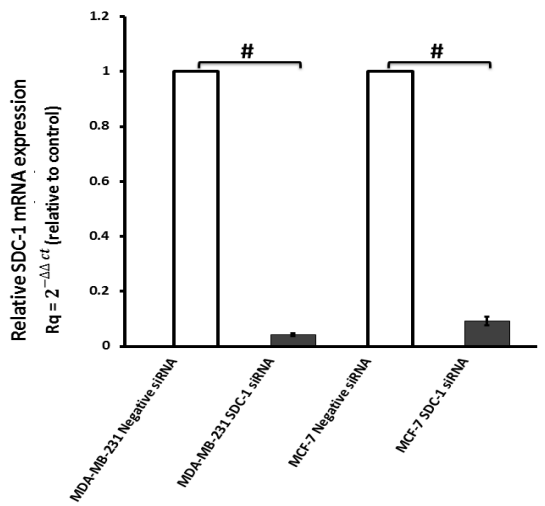

Fig. 1: qPCR for SDC-1 mRNA expression in control and SDC-1-depleted cells. SDC-1 mRNA was successfully knockdown in MDA-MB-231and MCF-7 breast cancer cell lines using siRNA approach. Total cellular RNA was isolated and reverse transcribed into cDNA and SDC-1 mRNA expression was checked using Taqman qPCR. The $2^{\wedge}(-\Delta \Delta$ ct)method was used to determine relative SDC-1 expression after normalization to $18 \mathrm{~S}$ rRNA. Data are mean $\pm \mathrm{SEM}$. $\# P<0.0001$ as determined by student t- test.

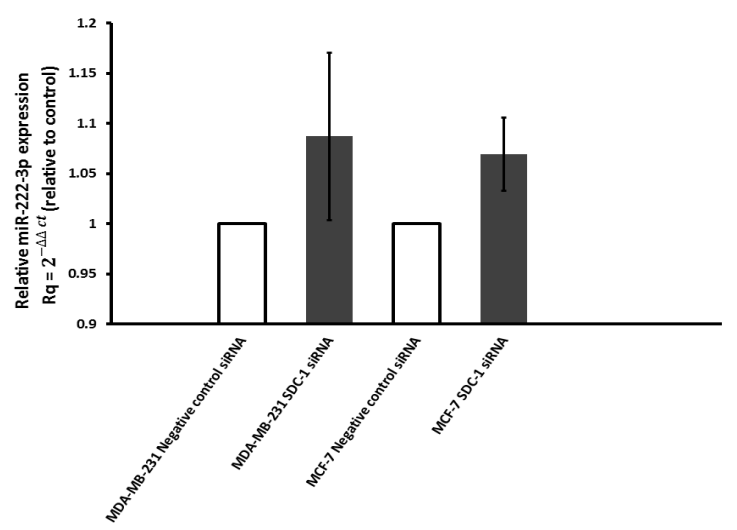

Fig. 2: SDC-1 knockdown has no effect on hsa-mir-222-expression in the MCF-7 and MDA-MB-231 cell lines. Total cellular RNA of control and SDC-1 siRNA transfected cells was isolated and reverse transcript to micro-cDNA. The $2^{\wedge}(-\Delta \Delta$ ct)method was used to determine relative miR-222levels after normalization to $18 \mathrm{~S}$ rRNA. Data are mean $\pm \mathrm{SEM}$.

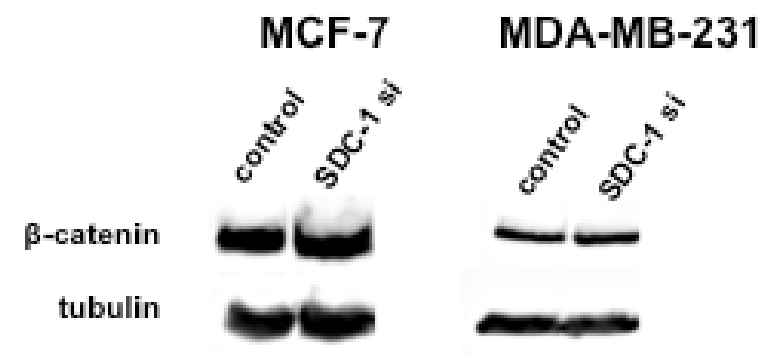

Fig. 3: No alteration in $\beta$ - catenin protein expression post SDC-1 silencing in MCF-7 and MDA-MB-231 cells. Total cell lysate of control and SDC1-silenced MCF-7 and MDA-MB-231 cells was subjected into western blot and probed with $\beta$-catenin and tubulin (loading control) antibodies. Data shown are duplicates from a single experiment as representative of three independent experiments.

\section{DISCUSSION}

It was reported that hsa-miR-222-3p regulates breast cancer metastasis and promotes the aggressive breast cancer phenotype which is resistant to some chemotherapy such as fulvestrant ${ }^{[13,21,22,]}$. In addition, it was proven that miR-222-3p inhibits many WNT/ $\beta$-catenin suppressors such as APC/ AXIN/ GSK3 $\beta$, resulting in WNT signaling activation in triple negative breast cancer $(\mathrm{TNBC})^{[23]}$. On the other hand, it was found that SDC-1 regulates WNT/ $\beta$-catenin signaling via binding its HS side chain with $\mathrm{R}$-spondin, leading to activation of LGR4 and resulting in suppression of Frizzled degradation and WNT/ $\beta$-catenin signaling activation in Multiple Myeloma ${ }^{[24]}$. In addition, it was proven that the SDC-1 HS chain is required for Wnt1-induced breast tumorigenesis in mice associated with an increase of cellular accumulated $\beta$ - catenin ${ }^{[25]}$. Takentogether, the previous findings prompted us to investigate the regulatory role of SDC-1 on miR-222-3p expression in breast cancer.

Our qPCR revealed that SDC-1 silencing did not affect miR-222-3p expression in both MCF-7 and MDAMB-231 cells. We have previously shown that SDC-1 knockdown resulted in enhanced migratory and invasive phenotype of MDA-MB-231 cells via modulation of RhoGTPase dependent modulation of cytoskeletal function and downregulation expression of the EMT marker E-cadherin ${ }^{[3]}$. miR-221/222 promotes EMT in breast cancer cell lines and tissues ${ }^{[26.27]}$. This suggests that SDC1 may modulate E-cadherin expression in breast cancer in miR-222-indepenedent mechanism.

This conforms to our previous findings that SDC1 depletion does not initiate but promote EMT once it is established in MCF-7 and MDA-MB-231 cells $^{[28]}$. Our Western blot showed that $\beta$-catenin expression was not altered upon SDC-1 depletion. It was reported that miR-222 over expression enhances constitutive activation of $\beta$-catenin in glioma cells ${ }^{[29]}$. Furthermore,miR-222/221 activates $\beta$-catenin expression in the nucleus of MCF7 and MDA-MB-231 cells via targeting many $\beta$-catenin 
suppressors such as wIF1, DKK2, SFRP2, or AXIN2 leading to promotion of carcinogenesis ${ }^{[30]}$ in addition, Wnt3a activation promote miR-221/222 expression in MDAMB-231 cells which suggests that positive feedback loop between $\mathrm{Wnt} / \beta$-catenin signaling and miR-221/222 may be present ${ }^{[23]}$. Therefore, our results suggest that SDC-1 could modulate breast cancer tumorgenesis through an alternative mechanism independent of miR-222/222- $\beta$ catenin axis pathway. Overall, we suggest that SDC-1 regulates expression of a wide range of other miRNAs, which are involved in modulating cancer cell behavior.

\section{CONFLICT OF INTEREST}

There are no conflicts of interest

\section{REFERENCES}

1. Bray F, Ferlay J, Soerjomataram I, Siegel RL, Torre LA and Jemal A: Global cancer statistics 2018: GLOBOCAN estimates of incidence and mortality worldwide for 36 cancers in 185 countries. CA Cancer J Clin., 2018; 68(6):394-424.

2. Ibrahim AS, Khaled HM, Mikhail NNH, Baraka H, and Kamel H: Cancer Incidence in Egypt: Results of the National Population-Based Cancer Registry Program. J Cancer Epidemiol., 2014; 437971

3. Ibrahim SA, Yip GW, Stock C, Pan JW, Neubauer C, Poeter M, Pupjalis D, Koo CY, Kelsch R, Schüle R, Rescher U, Kiesel L and Götte M: Targeting of syndecan-1 by microRNA miR-10b promotes breast cancer cell motility and invasiveness via a Rho-GTPase- and E-cadherin-dependent mechanism. Int. J. Cancer, 2012; 131 (6): E884-96.

4. Nikolova V, Koo CY, Ibrahim SA, Wang Z, Spillmann D, Dreier R, KelschR, Fischgräbe J, Smollich M, Walter R, Sibrowski SP, Kiesel L, George WY and Götte $\mathrm{M}$ :Differential roles for membrane-bound and soluble syndecan-1 (CD138) in breast cancer progression Carcinogenesis, 2009; 30 (3) $1: 397-407$.

5. Gotte M, Kersting C, Radke I, Kiesel L and Wulfing P: An expression signature of syndecan-1 (CD138), E-cadherin and c-met is associated with factors of angiogenesis and lymph angiogenesis in ductal breast carcinoma in situ. Breast Cancer Res., 2007; 9 (1): R8.

6. Hassan H, Greve B, Pavao MSG, Kiesel L, Ibrahim SA and Götte M: Syndecan-1 modulates $\beta$-integrin-dependent and interleukin-6-dependent functions in breast cancer cell adhesion, migration, and resistance to irradiation. FEBS, 2013; 280 (10): 2216-222.

7. Purushothaman A and Sanderson RD: SDC1 (syndecan 1). Atlas Genet. Cytogenet. Oncol. Haematol., 2009; 13 (1): 57-61.
8. Lewis BP, Burge CB and Bartel DP:Conserved seed pairing, often flanked by adenosines, indicates that thousands of human genes are microRNA targets. Cell, 2005; 120 (1): 15-20.

9. Garzon R, Fabbri M, Cimmino A, Calin GA and Croce CM: MicroRNA expression and function in cancer. Trends Mol Med., 2006; 12: 580-587.

10. Fujii T, Shimada K, Tatsumi Y, Fujimoto K and Konishi N: Syndecan-1 responsive microRNA-126 and 149 regulate cell proliferation in prostate cancer. Biochem. Biophys. Res. Commun., 2015; 456: 183-189

11. Fujii T, Shimada K, Tatsumi Y, Fujimoto K, Tanaka N and Konishi N: Syndecan-1 upregulates microRNA-331-3p mediates epithelial-tomesenchymal transition in prostate cancer. Mol. Carcinogen., 2016; 55 (9): 1378-1386

12. Di Leva G, Gasparini P, Piovan C, Ngankeu A Garofalo M, Taccioli C, Iorio MV, Li M, Volinia S, Alder H, Nakamura T, Nuovo G, Liu Y, Nephew KP and Croce CM: MicroRNA cluster 221-222 and estrogen receptor alpha interactions in breast cancer. J Natl. Cancer Inst., 2010; 102 (10): 706721.

13. Stinson S, Lackner MR, Adai AT, Yu N, Kim HJ, O'Brien C, Spoerke J, Jhunjhunwala S, Boyd Z, Januario T, Newman RJ, Yue P, Bourgon R, Modrusan Z, Stern HM, Warming S, de Sauvage FJ, Amler L, Yeh RF and Dornan D: Mir-221/222 targeting of trichorhinophalangeal 1 (TRPS1) promotes epithelial -to- mesenchymal transition in breast cancer. Sci. Signal., 2011; 4 (186): pt5.

14. Hwang MS, Yu N, Stinson SY, Yue P, Newman RJ, Allan BB and Dornan D: MiR-221/222 targets adiponectin receptor 1 to promote the epithelialto-mesenchymal transition in breast cancer. PLoS One, 2013; 8 (6): e66502.

15. Nassirpour R, Mehta PP, Baxi SM and Yin M-J: MiR-221 promotes tumorigenesis in human triple negative breast cancer cells". PLoS One, 2013; 8(4):e62170.

16. Garofalo M, Di Leva G, Romano G, Nuovo G, Suh SS, Ngankeu A, Taccioli C, Pichiorri F, Alder H, Secchiero P, Gasparini P, Gonelli A, Costinean $S$, Acunzo M, Condorelli $G$ and Croce $C M$ : miR-221\&222 regulate TRAIL resistance and enhance tumorigenicity through PTEN and TIMP3 downregulation. Cancer Cell, 2009; 16(6):498-509.

17. $\mathrm{Su} \mathrm{A}, \mathrm{He} \mathrm{S}$, Tian $\mathrm{B}, \mathrm{Hu} \mathrm{W}$ and Zhang $\mathrm{Z}$ : MicroRNA-221 mediates the effects of PDGF$\mathrm{BB}$ on migration, proliferation, and the epithelialmesenchymal transition in pancreatic cancer cells PLoS One, 2013; 8 (8): e71309. 
18. Qin J and Luo M: MicroRNA-221 promotes colorectal cancer cell invasion and metastasis by targeting RECK. FEBS Lett.2013; 588 (1): 99-104.

19. Ying X, Wu Q, Wu X, Zhu Q, Wang X, Jiang L, Chen $X$ and Wang $X$ : Epithelial ovarian cancer secreted exosomal mir-222-3p induces polarization of tumor- associated macrophages. Oncotarget., 2016; 7 (28): 43076 - 43087.

20. Liu B, Che Q, Qiu H, Bao W, Chen X, Lu W, Li $\mathrm{B}$ and Wan X: Elevated mir-222-3p promotes proliferation and invasion of endometrial carcinoma via targeting ERa. PLoS One, 2014; 9 (1): e87563.

21. Shah MY and Calin GA: MicroRNAs mir-221 and mir-222: a new level of regulation in aggressive breast cancer. Genome Med., 2011; 3 (8): 56.

22. Rao X, Di Leva G, Li M, Fang F, Devlin C, Hartman-Frey C, Burow ME, Ivan M, Croce CM and Nephew KP: MicroRNA -221/222 confers breast cancer fulvestrant resistance by regulating multiple signaling pathways. Oncogene, 2011; 30 (9): 1082-1097.

23. Liu S, Wang Z, Liu Z, Shi S, Zhang Z, Zhang J and Lin H: MiR-221/222 activate the Wnt/ $\beta$-catenin signaling to promote triple-negative breast cancer. J. Mol. Cell Biol., 2018; 10 (4): 302-315.

24. Ren Z, van Andel H, de Lau W, Hartholt RB, Maurice MM, Clevers H, Kersten MJ, Spaargaren $M$ and Pals ST: Syndecan- 1 promotes $W n t / \beta$ catenin signaling in multiple myeloma by presenting Wnts and R-spondins. Blood, 2018; 131 (9): 982-994.
25. Alexander CM, Reichsman F, Hinkes MT, Lincecum J, Becker KA, Cumberledge $\mathrm{S}$ and Bernfield M: Syndecan-1 is required for Wnt-1induced mammary tumorigenesis in mice. Nat. Genet., 2000; 25: 329-332.

26. Han S-H, Kim HJ, Gwak JM, Kim M, Chung YR and Park SY: MicroRNA-222 expression as a predictive marker for tumor progression in hormone receptor-positive breast cancer. J Breast Cancer, 2017; 20 (1): 35-44.

27. Liang YK, Lin HY, Dou XY, Chen M, Wei XL, Zhang YQ, Wu Y, Chen CF, Bai JW, Xiao YS, Qi YZ, Frank A. E. and Zhang GJ:MiR-221/222 promote epithelial-mesenchymal transition by targeting Notch3 in breast cancer cell lines. NPJ Breast Cancer, 20186 (4):20.

28. Ibrahim SA, Hassan H, Vilardo L, Kumar SK, Kumar AV, Kelsch, Cornelia Schneider R, Kiesel L, Eich HT, Zucchi I, Reinbold R, Greve B, and Martin Götte : Syndecan-1 (CD138) Modulates Triple-Negative Breast Cancer Stem Cell Properties via Regulation of LRP-6 and IL6-Mediated STAT3 Signaling. PLoS One, 2013; 8(12): e85737.

29. Liu S, Wang Z, Liu Z, Shi S, Zhang Z, Zhang J, Lin $H:$ miR-221/222 activate the Wnt/ $\beta$-catenin signaling to promote triple-negative breast cancer. J Mol Cell Biol., 2018; 10(4):302-315.

30. Li Q, Shen K, Zhao Y, He X, Ma C, Wang L, Wang B, Liu J, Ma J: MicroRNA-222 promotes tumorigenesis via targeting DKK2 and activating the Wnt/ $\beta$-catenin signaling pathway. FEBS Lett., 2013; 587(12):1742-8. 


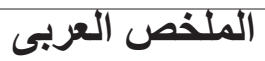

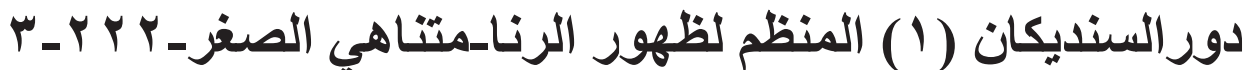 بيفي الخلايا السرطانية لثدي الإنسان}

ז،'سحر محمد إبراهيم، 'أمل إبراهيم عثمان ، 'هبة الله حسن، 'شريف عبد العزيز إبراهيم، 'مارتن جوت اهت

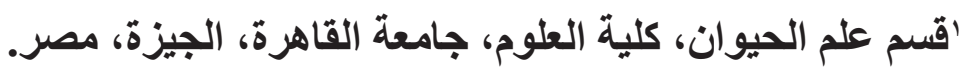

"قسم أمراض النساء والتوليا، مشفى مونستر الجامعي، مونستر، ألمانيا

المقدمة: الرنا_متناهي الصغر هي جزيئات من الحمض النووي التي يتر اوح طولها بين 25-18 من النيوكليوتيدات، و هي تشارك في تنظيم العديد من العمليات الفسيولوجية والمرضية. و أفادت الابحاث السابقة بأن الرنا_متتاهي الصغر 22-3- بي، ينظم عدو انية سرطان الثذي في مر احلة الأولي ونموة الثانوي في اماكن اخرى. سنديكان (1) هو عبارة عن سلفات الكبريتيوجد على سطح الخلية و يعمل كمستقبل مساعد للعديد من مستقبلات عوامل النمو ، ومن المعروف أنه ينظم ظهور العديد من جزيئات الرنا_المتناهية الصغرو لايز ال تأثنيره على الرنا-متناهي الصغر 222- في سرطان الثني غير و اضح.

الهدف من البحث: للتحقق من تأثثر سنديكان (1) على ظهور الرنا_متناهي الصغر 222-3- بي، في خطوط خلايا سرطان الثدي في الانسان. مواد وطرق البحث: تم زر ع خطوط خلايا سرطان الثدي للإنسان (MCF-7 و MDA-MB-231) مع الخلايا الحاكمة، و الرنا_قصير التداخل تعطيل السنديكان (1) عن العمل، وتم تحليل ظهور الرنا_متناهي الصغر 3-222- بي، بواسطة جهازبيسي آر الكمي.وكذاللك، تم تقييم ظهوربروتين البيتا_الكاتينين بعد عملية تعطيل السنديكان (1) عن العمل، بواسطة الويسترن بلوت. النتائج: لم يلاحظ أي تغير ملحوظ لمستويات ظهور الرنا_متناهي الصغر 3-222- بي و بروتين البيتا_الكاتينين بعد عملية تعطيل السنديكان (1) عن العمل في خطوط الخلايا MCF-7 و MDA-MB-231. الإستتتاج: لا يُعد السنديكان (1) منظمًا لظهور الرنا_متناهي الصغر 3-222- بيولا لتغير السلوك الخلويفي خلايا سرطان الثذي و على ذلك تعتبر عدو انية خلايا MDA-MB-231 وخلايا MCF-7 مستقلة عن الرنا_متناهي الصغر 222-3 